\title{
Influence of the form of nitrogen nutrition on foliar nitrate reductase activity in young black locust (Robinia pseudoacacia L.)
}

\author{
F. Boutekrabt and G. Pizelle \\ Laboratoire de Physiologie Végétale et Forestière, Faculté des Sciences, BP 239, 54506 \\ Vandceuvre-lès-Nancy Cedex, Francqe
}

\section{Introduction}

Robinia pseudoacacia L. fixes dinitrogen in symbiosis with a specific rhizobium and, as a nitrogen-fixing tree, gives a litter with a low C/N (Moiroud and Capellano, 1981), which favors nitrification (Montagnini et al., 1986).

In the field, black locust can therefore use both symbiotic and nitrate nitrogen. Data on the nitrate reduction in $R$. pseudoacacia are still very limited (Aznadi, 1984). The present work examines the effects of the symbiotic and nitrate nitrogen nutritions on the leaf nitrate reductase activity and the distribution of this enzyme activity in young black locusts.

\section{Materials and Methods}

Young black locusts inoculated with a suspension of crushed nodules were grown on a nitrogen-free nutrient solution in a growth chamber. Nitrate nutrition of the nodulated plants was assured by the addition of 4 or $10 \mathrm{mM} \mathrm{NaNO}_{3}$ to the nitrogen-free solution.
Nitrogenase $\left(\mathrm{N}_{2}\right.$ ase) activity was measured on intact plantlets by the acetylene reduction method. Nitrate reductase (NR) activity was measured in vivo on leaf disks (diameter: 12 $\mathrm{mm}$ ). Two disks were vacuum infiltrated in $3 \mathrm{ml}$ of $0.1 \mathrm{M} \mathrm{NaK}$ phosphate buffer, $\mathrm{pH} 7.5$, containing $0.05 \mathrm{M} \mathrm{KNO}_{3}$ and Triton $X-100(0.1 \%, v / v)$. After incubation for $1 \mathrm{~h}$ at $30^{\circ} \mathrm{C}$ in the dark, $\mathrm{NO}_{2}^{-}$was determined spectrometrically at 540 $\mathrm{nm}$ in the incubation medium.

\section{Results}

Presence of a constitutive leaf NR activity affected by the $\mathrm{N}_{2}$ ase activity

The leaves of nitrogen-deficient plants had a notable NR activity considered as constitutive, since it was not induced by nitrate (Fig. 1). This enzyme activity decreased to a minimum value $(\leq 1 \mathrm{nmol}$ $\mathrm{NO}_{2}^{-} \cdot \mathrm{mg}^{-1} \mathrm{DW} / \mathrm{h}^{-1}$ ) when the $\mathrm{N}_{2}$ ase increased after nodulation. When symbiotic nitrogen nutrition was eliminated by excision of root nodules, a notable NR activity was progressively recovered in the leaves (results not shown). 


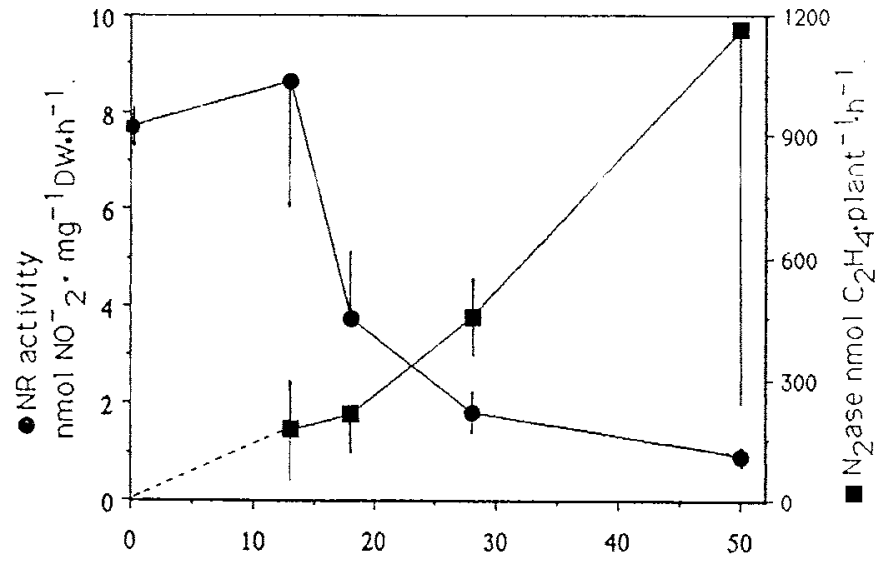

Days after nodule appearance

Fig. 1. Variation of foliar NR activity and nitrogenase activity after nodulation in young black locusts inoculated with crushed nodules at 1.5 mo old. Means of 4 replicates \pm SE.

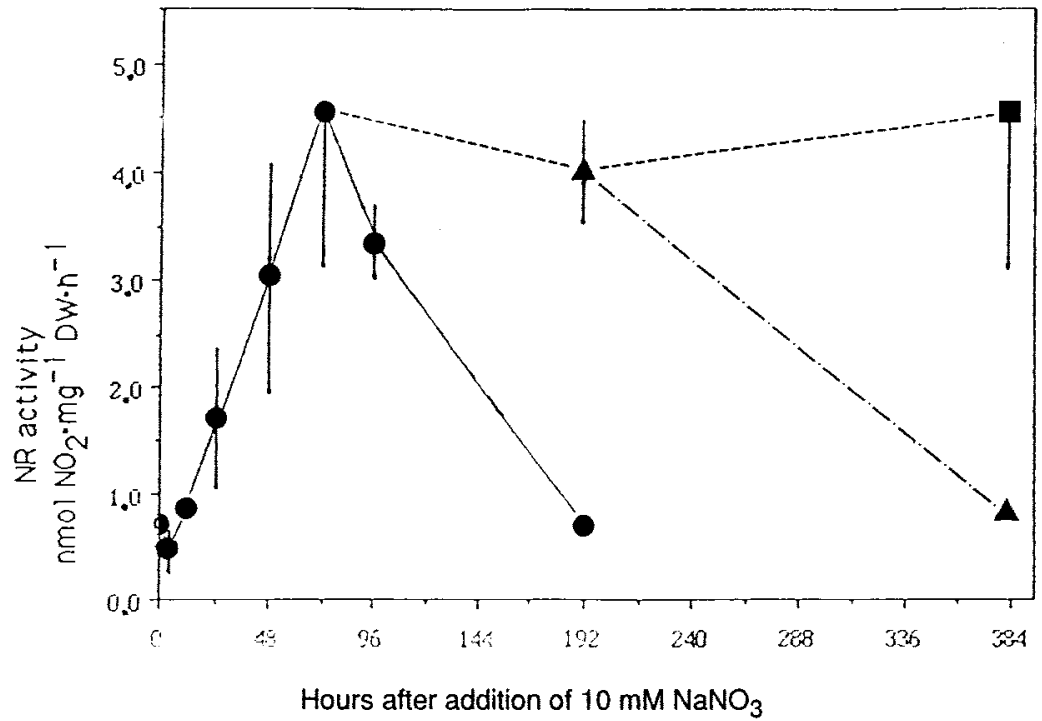

Fig. 2. Induction of foliar NR activity by nitrate $\left(10 \mathrm{mM} \mathrm{NaNO}_{3}\right)$ in 11 mo oid black locusts. The assays were made on the youngest fully expanded leaves successively $(\boldsymbol{\theta}, \boldsymbol{\Delta}$, then $\boldsymbol{E}$ ) developed during the experiment. Means of 3 replicates $\pm S E$ (when size of $S E>$ size of symbol). 
Effect of nitrate of leaf NR activity of nodulated plants

Administration of $4 \mathrm{mM} \mathrm{NaNO}$ to 11 mo old nodulated plants did not increase leaf $\mathrm{NR}$ activity, whereas the $10 \mathrm{mM} \mathrm{NaNO}$ dose induced high enzyme activity (Fig. 2). After $72 \mathrm{~h}$ of induction, the highest NR activity was found in the apical fully expanded leaf and corresponded with the highest nitrate content (Table I). When a

Table I. Nitrate content ( $\left.\mathrm{N}-\mathrm{NO}_{3} \%, \mathrm{DW}\right)$ in the apical, median and basal leaves of nodulated 11 mo old plants supplied with $10 \mathrm{mM} \mathrm{NaNO}$ for $96 \mathrm{~h}$.

\begin{tabular}{lll}
\hline Leaf & \multicolumn{2}{l}{ Symbiotic $\mathrm{N}$-nutrition } \\
\cline { 2 - 3 } position & control plants & $+\mathrm{NaNO}_{3}(10 \mathrm{mM})$ \\
\hline Apical & 0 & 1.560 \\
Median & 0 & 0.128 \\
Basal & 0 & 0.073 \\
\hline
\end{tabular}

One measurement. new leaf expanded, the NR activity decreased in the previous leaf and the highest enzyme activity was found again in the new leaf (Fig. 2).

When the nitrate supply was withdrawn, the enzyme activity recovered its minimum value after $2 d$ (Fig. 3).

\section{Conclusion}

Notable NR activity $\left(6-9 \mathrm{nmol} \mathrm{NO}_{2}^{-} \cdot \mathrm{mg}^{-1}\right.$ $\mathrm{DW} \cdot \mathrm{h}^{-1}$ ) was measured in vivo in the leaves of young nitrogen-deficient $R$. pseudoacacia; its role is unknown, but its decrease, concomitant with the advent of the $\mathrm{N}_{2}$ ase activity, indicates a relationship between both enzyme activities. The low $\mathrm{NR}$ activity $\left(\leq 1 \mathrm{nmol} \mathrm{NO}-\cdot \mathrm{mg}^{-1} \mathrm{DW} \cdot \mathrm{h}^{-1}\right)$ of nodulated plants could be greatly increased by nitrate supplied via the roots. This inducible NR activity was consistently

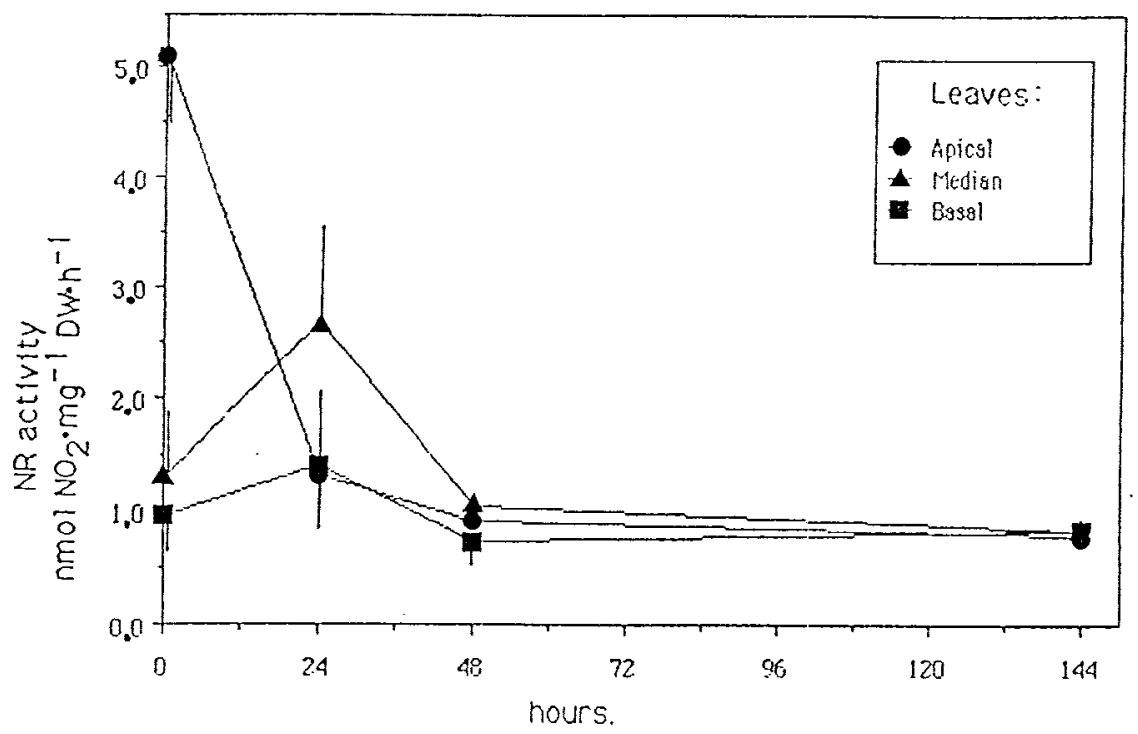

Fig. 3. Effect of the elimination of nitrate supply (at $0 \mathrm{~h}$ ) on the NR activity in apical, median and basal leaves of 11 mo old black locusts. Means of 3 replicates $\pm \mathrm{SE}$ (when size of $\mathrm{SE}>$ size of symbol). 
highest in the younger expanded leaves that showed the highest nitrate content. Studies are in progress to compare these results with those obtained on leaves from field-grown $R$. pseudoacacia.

\section{References}

Aznadi A. (1984) Etude de l'influence de quelques herbicides sur la croissance et la nutrition azotée du robinier (Robinia pseudoacacia L.). Thesis 3rd Cycle, Université de Nancy I, France

Moiroud A. \& Capellano A. (1981) Fixation d'azote chez les espèces ligneuses symbiotiques. II. Reprise de l'activité fixatrice (réduction de $\mathrm{C}_{2} \mathrm{H}_{2}$ ) chez Robinia pseudoacacia L. au printemps. Bull. Soc. Bot. 128, 239-247

Montagnini F., Haines B., Boring L. \& Swang W. (1986) Nitrification potentials in early successional black locust and in mixed hardwood forest stands in the southern Appalachians. Biogeochemistry 2, 197-210 